\title{
A REVISION OF THE RONA MEMBER
}

\author{
VLAD A. CODREA ${ }^{1}$, EMANOIL SĂ SĂ RAN ${ }^{1}$
}

\begin{abstract}
Lacustrine deposits occurring in the Jibou Formation (Late Maastrichtian - Lutetian) were mentioned in the Rona village area since the first half of the $19^{\text {th }}$ century. Hungarian and Romanian geologists also carried out several researches in the last century, referring to the so-call "Rona Limestone" or "Rona Member". In the last years, new outcrops resulted as a consequence of works made for the Botanical Garden at Jibou, adding details concerning mainly the base of the lacustrine succession. The new geological section from Jibou Botanical Garden should complete the old stratotype of the „Rona Limestone”, as a hypostratotype.
\end{abstract}

KEYWORDS: Paleogene Transylvanian Basins; stratigraphy; Paleocene; Jibou Formation; Rona Member; hypostratotype.

\section{INTRODUCTION}

In the NW region of the Transylvanian Depression, the Cenozoic sedimentation begins with the Jibou Formation, a considerable thick pile of red deposits (over $1500 \mathrm{~m}$ ) developed in fluvial and lacustrine facies. The lowermost base of this formation still belongs to the Latest Cretaceous, which evolved in the same depositional context. In this manner, the Jibou Formation represents one of the post-Laramian covers from Apuseni M-ts, lying here over the Inner Dacids structures (Să ndulescu, 1984).

For the Eocene sedimentation, Popescu (1976) separed in this region three depositional areas: Gilă u, Mezes and Preluca. It is important to mention that in all these areas, the Jibou Formation has a remacable constance.

The Jibou Formation's lithology consists in red siltic clays, representing the overbanck deposits interrupted by channel fills, where polygenous conglomerates, microconglomerates and red sandstones are the dominant rocks. In some areas, the base of the formation begins with a level of breccias with reworked components of the older basement (Rusu, 1995). The rule was broken in the lacustrine episodes, where the lithology is more diverse, with limestone, marl and even coal thin strata.

For a very long time, the formation seemed to be devoid of fossils. In his monograph concerning the Paleogene from Transylvania, Koch (1894) reported: "It is regrettable the fact that in the whole series of the variegated clays, one could not find nor even any trace of organic remains, so that for the detailed stratigraphical investigation of these strata devoid of fossils, one can use as guide only some petrographically characters".

\footnotetext{
${ }^{1}$ Babeş-Bolyai University, Faculty of Biology and Geology, Department of Geology-Paleontology, 1 Kogălniceanu Str., 3400 Cluj-Napoca. E-mail:vcodrea@bioge.ubbcluj.ro; esasaran@bioge.ubbcluj.ro
} 


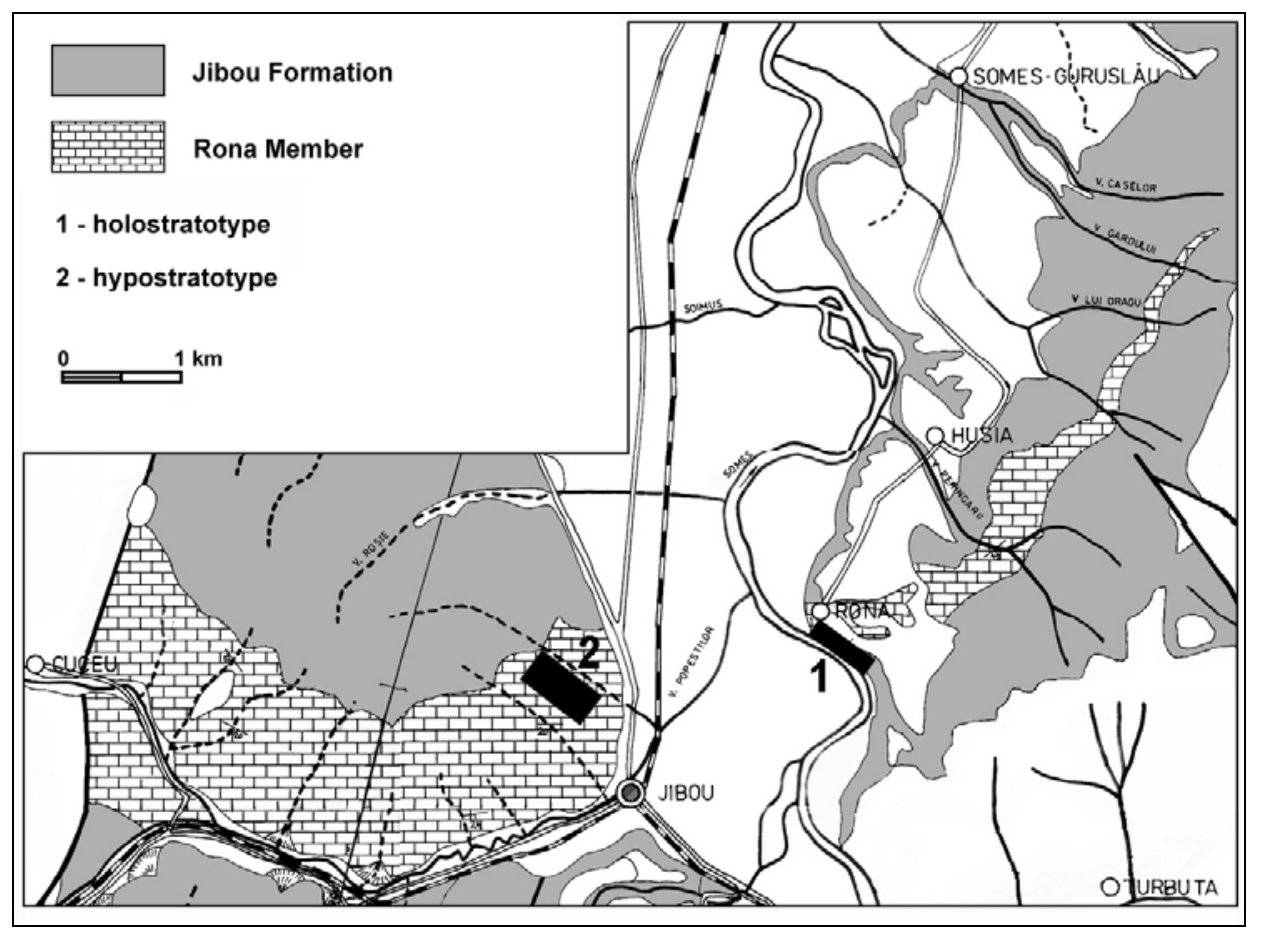

Fig. 1 - Location of the stratotypes on the geological map

However, the next investigations carried on after Koch's study, evidenced the existence of several fossils. Nopcsa (1905) mentioned a problematic dinosaur rib fragment, as well as some crocodilian and turtle remains from Someș Odorhei, not far from Jibou. On this basis, he argued that the base of the Jibou Formation belongs to the Latest Cretaceous (Maastrichtian). In our recent (2002) field mission, we succeed in finding several vertebras and a half of tibia belonging to an Ornithopod dinosaur, confirming Nopcsa's stratigraphical viewpoint.

In another area where the Jibou Formation is cropping out, at Giurtelecul Șimleului, near the top of the succession, several turtle remains were also discovered, assigned to "Palaeochelys" sp. s.l. and Neochelys sp. (Codrea \& Fă rcaș, 2002). These taxa could indicate a Lower Eocene age for the top of the Jibou Formation.

In the lacustrine deposits interbedded in the Jibou Fm succession, the fossils are richer: charophytes, pollen, fish, crocodiles, turtles and mammals can be studied in such sediments.

However, the lacustrine episodes were rare in this area between the Latest Cretaceous and the Early Eocene. Such kind of deposits can be observed only at Rona-Jibou (Să laj district, Meseș area), Horlacea and Hă șdate (Cluj district, Gilă u area). Among these lacustrine deposits, the main one is located at Rona-Jibou, where the so-called "Rona Limestone" is cropping out. 


\section{GEOLOGICAL SETTING}

G. Stache was the first to discover between 1859-1860 the Rona Limestone, as mentioned by Hofmann (1879). However, only Hofmann himself gave a detailed description of these lacustrine deposits.

Mészàros \& Moisescu (1991) recently presented a historical evolution of the stratigraphical names for the Jibou Formation (Rona lacustrine deposits included).

All the contributors mentioned by Mészàros \& Moisescu, considered the "Rona Limestone" stratotype located on the Someș River left banck, at Rona. A detailed lithostratigraphical, petrographical and microfacial desciptions of this stratotype belongs to Bombit ă \& Baltres (1986). The Figs. 1 and 2 of these authors' contribution, clear demonstrates that the type-section was located only in Rona area, in a wide meander made by Someș. In their opinion, the age of the "Rona Limestone" was Lower-Middle Eocene.

In the last two decades, several works took place at Jibou, carried on for fitting out the Botanical Garden. On this opportunity, a lot of new outcrops begun available for study, offering a new section of the "Rona Limestone" succession. This new log revealed that in fact, what it was know as "Rona Limestone" represented only a small part of the lacustrine deposits.

The new outcrops were studied mainly for fossil algae (Baciu, 1997), pollen (Petrescu, unpublished data, personal communication) and vertebrates (Gheerbrant et al., 1999). On this basis, Codrea et al. (2000), proposed to outline a protected area inside the Botanical Garden courtyard.

However, a detailed and complete geological log of this section was never done. Gheerbrant et al. (1999), presented a simplified log, showing the phases of the lake evolution. Baciu (1997) published a part of the geological log, but it represents only partially the Botanical Garden succession (Bucur et al., 2001).

Concerning the litostratigraphy, it worth to be outlined that the firsts who considered the "Rona Limestone" in a member sense, were Ră ileanu \& Saulea (1956), as Popescu (1978) mentioned. Later, Filipescu (1997, 2001) mentioned also the Rona Member. However, neither the firsts, nor the second of these contributors, gave a clear and detailed definition of the Rona Member.

In these circumstances, this paper will be a tentative for a complete definition of the Rona Member, with a detailed description of the geological log from the Botanical Garden section. This section should be considered as a part of a composite stratotype, i.e. a hypostratotype.

\section{THE RONA MEMBER, HOFMANN 1879 (emended)}

\section{Composite stratotype:}

1. Holostratotype: the classical Hofmann's type-section, located on the Someș River left bank, at Rona (Profile A);

2. Hypostratotype: the section located in the area of the Botanical Garden Jibou, between Valea Viilor and the hill named "La Criptă " (Profile B).

Geological age: Thanetian - (?) Sparnacian.

Lower boundary: The first lacustrine sequence, replacing the flood plain facies of Jibou Fm. This boundary is cropping out on Valea Viilor, where the stream penetrates in the Botanical Garden area. 


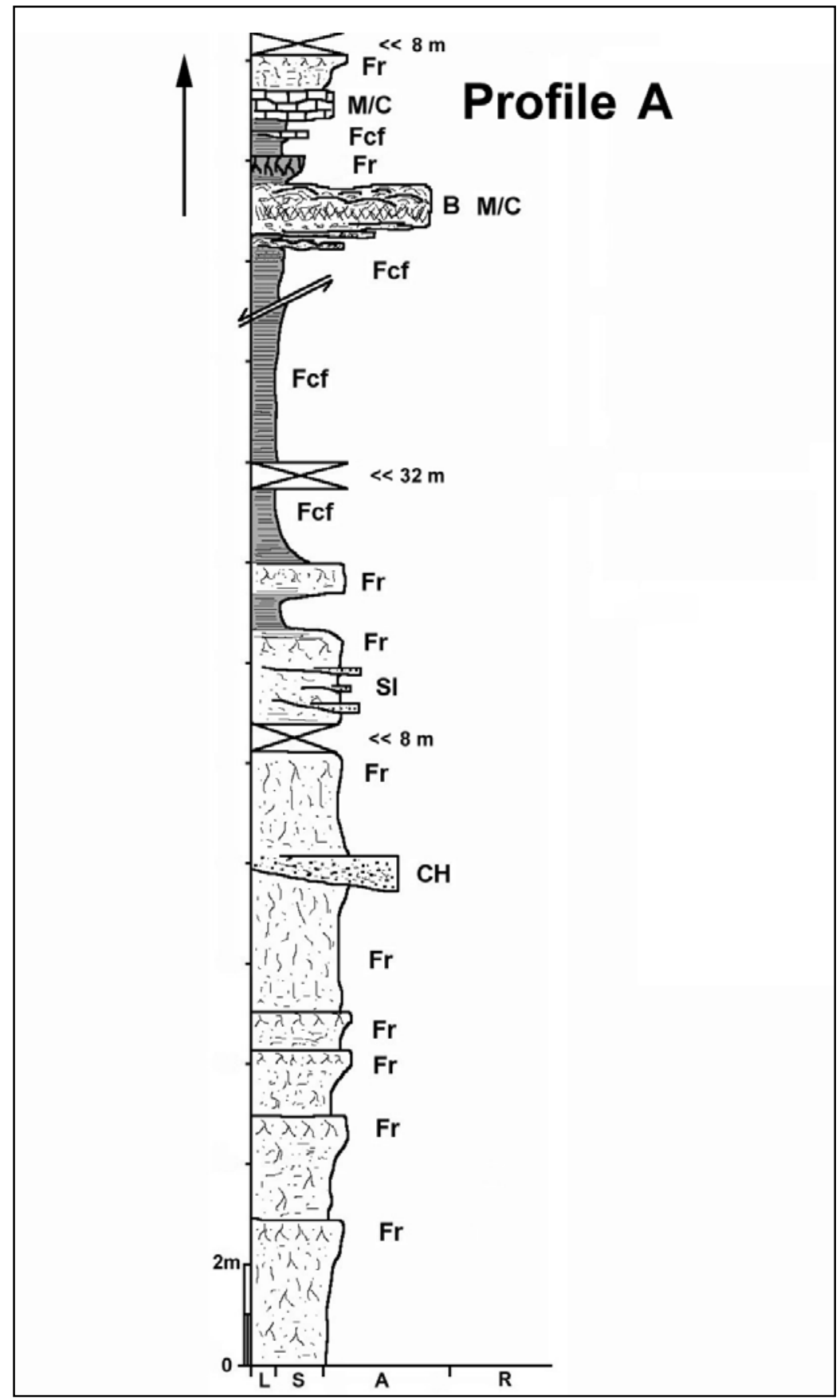




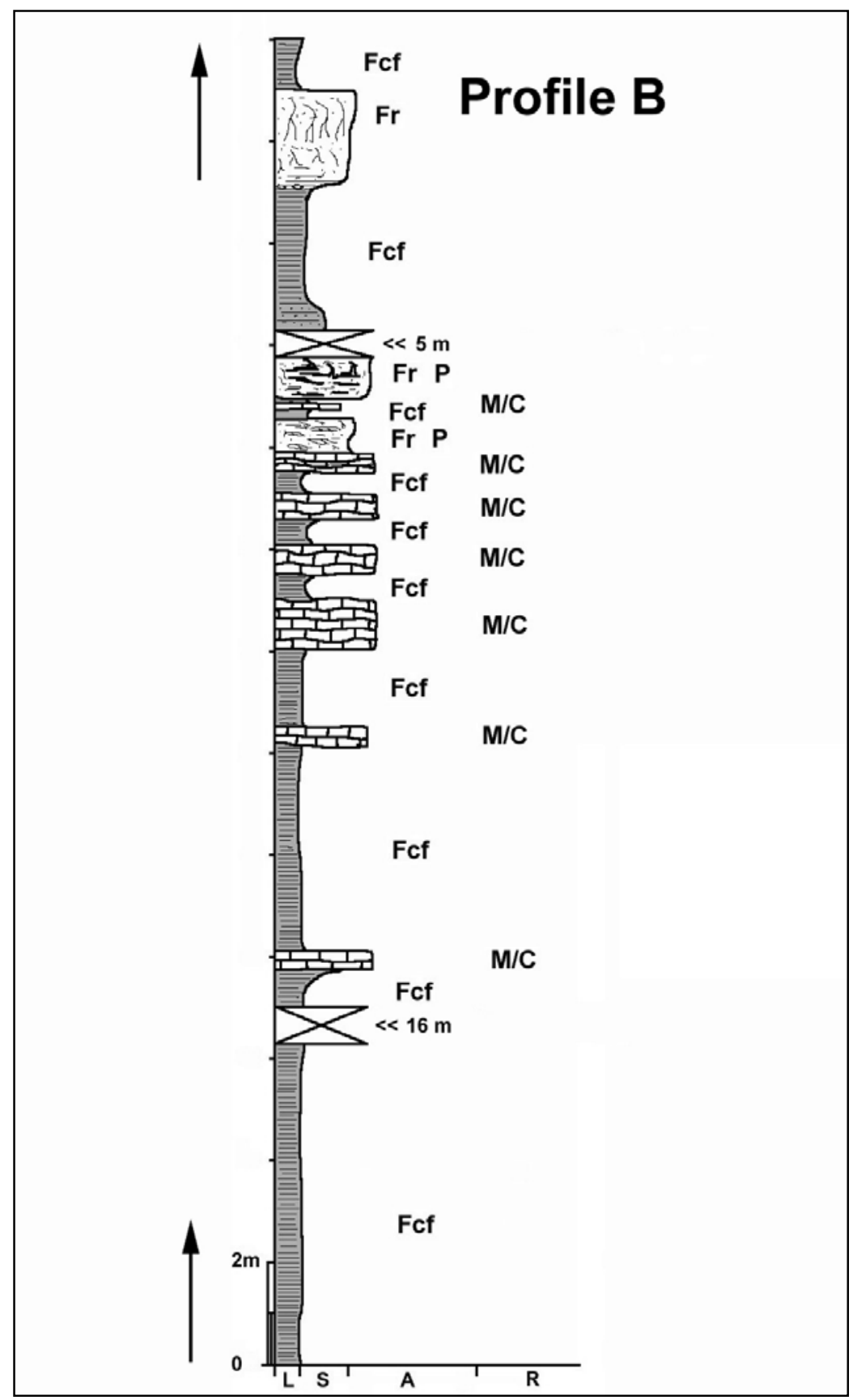




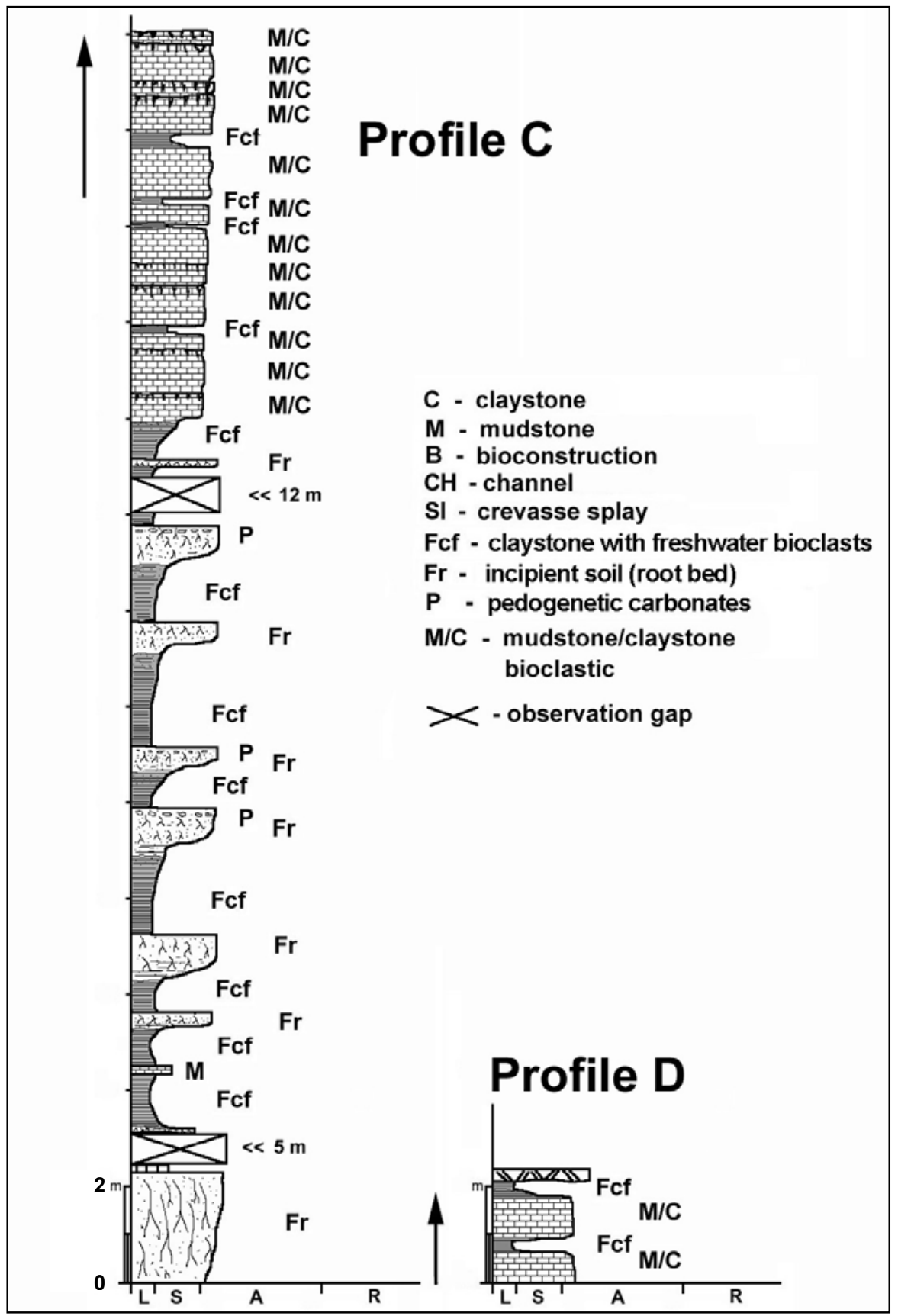


Upper boundary: The last lacustrine sequence, directely covered by the flood plain facies of Jibou Fm. This boundary is cropping out on the classical Hofmann's section at Rona, on the left Somes River bank, upstream from the village, in the area of a maximum concavity of a wide meander made by the river.

Description of the new section from the Botanical Garden Jibou: Baciu (1997) was the first to mention some data concerning the lower boundary, without indicating however, the clear geographical location of this limit.

Lithologically, the first lacustrine deposits cropping out in the left bank of Valea Viilor correspond to bioclastic claystone/mudstone, with ostracods, charophytes, crocodile teeth and fish scales (see details in: Profile A), representing the first flooding event.

The hypostratotype succession includes facies starting with relative deep (below the wave base) lacustrine deposits from shallow ones, and rarely even to marginal swamps with subaerial episodes (Profile A-D). These last, are the best suitable sequences for vertebrates and microvertebrates fossils (crocodiles, turtles, mammals; Gheerbrant et al., 1999).

The marl pile mentioned by Baciu (1997) and Gheerbrant et al. (1999), is not so monotonous as it was suggested, because inside this sequence, several emerging episodes had been distinguished (Profile B-C).

The top of the succession cropping out in "La Criptă " hill, dominated by mudstone/claystone, corresponds to the base of the classical stratotype from Rona village.

\section{CONCLUSIONS}

The Paleocene lacustrine deposits that can be followed in Să laj district, between Cuceu and Husia villages, represent a very peculiar depositional episode inside the Jibou Formation (Latest Cretaceous-Early Eocene). The area where this lacustrine succession has its main vertical extension is located between the village of Rona and the town of Jibou.

These lake deposits worth to be separed as a local member of the Jibou Formation, the Rona Member.

The classical type-section from Rona, firstly mentioned and described by Stache and later, by Hofmann (1879), represent only the top of the Rona Member. This section is convenient only for separing the last phase in the lake evolution, i.e. the lake infilling. In this respect, the name "Rona Limestone" is not an appropriate one, because the limestone has only a minor participation inside this succession. The upper limit of the Rona Member is cropping out on the left bank of the Somes River, upstream from Rona, where the river made a wide meander. It corresponds to the last lacustrine episode and to the transition to the flood plain facies, represented by red siltic clays and sandstones.

The new section, cropping out inside the area of the Botanical Garden from Jibou corresponds mainly to the lake extension. It should be considered as a hypostratotype, completing the Rona classical stratotype. 
The age of the Rona Member is Paleocene and perhaps, the Lowermost Eocene, i.e. the Thanetian and (?) Sparnacian (Gheerbrant et al., 1999).

The paleontological evidence cannot support a Lutetian age for the Rona Member, as suggested by several geologists (e.g. Bombiț ă \& Baltreș, 1986; Mészàros, 1995).

Acknowledgements. Authors express their sincere thanks to several colleagues from Babeş-Bolyai University of Cluj, involved in the last field missions works at Jibou: Prof. dr. Iustinian Petrescu, Paul Dica, Matei Vremir, Fărcaş Cristina, Liana Săsăran, Dr. Ovidiu Barbu, Claudiu Chendeş, Sergiu Hossu, Ana Varga, Vasile Vari and several other undergraduate students. This research was supported by the National Geographic Foundation's Grant \# 7085-01 (V. Codrea) and partially by CNCSIS's Grant \#1243/2002 (project leader: V. Codrea)

\section{REFERENCES}

BACIU, C., 1997, Câteva specii de charophyte din partea inferioară a Calcarului de Rona. Natura Silvaniae, 1: 153-161, Jibou.

BOMBIȚĂ , G., BALTREȘ, A.,1986, Contributions à l'étude des calcaires lacustres éocènes de Transylvanie. Dă ri de seamă ale ședinț elor. 70-71 (1983-1984), 4. STRATIGRAFIE, 227-244, Institutul de Geologie și Geofizică , București.

BUCUR, I.,I., BACIU, C., HOSU, A., CODREA, V., 2001, Eocene red algae and Paleocene charophytes of Jibou area. Field Trip Guide, 4-th Regional Meeting of IFAA: 209221, Cluj-Napoca.

CODREA, V., FATI, V., BACIU, C., VREMIR, M., TANȚĂ U, I., HOSU, AL., DICA, P., SĂ SĂ RAN, E., 2000: Argumente pentru amenajarea unei rezervat ii geologicepaleontologice în perimetrul Gră dinii Botanice Jibou (jud. Să laj). Studii și cercetă ri (Geologie-Geografie), 5: 35-42, Bistriț a.

CODREA, V., FĂ RCAȘ, C., 2001, Principalele asociații de tetrapode continentale paleogene din Transilvania: distribuț ie stratigrafică și semnificat ii paleoambientale. Armonii Naturale, IV/2:80-92, Arad.

FILIPESCU, S., 1997, Several comments on the nomenclature of the litostratigraphic units from the Transylvanian Depression. Studia Universitatis Babeș-Bolyai, Geologia, XLII, 2: 81-85, Cluj-Napoca.

FILIPESCU, S., 2001, Cenozoic lithostratigraphic units in Transylvania. Field Trip Guide, 4th Regional Meeting of IFAA: 75-92, Cluj-Napoca. 
GHEERBRANT, E., CODREA, V., HOSU, AL., SEN, S., GUERNET, C., LAPPARENT, DE BROIN, FR., RIVELINE, J., 1999, Découverte de vertébrés dans les Calcaires de Rona (Thanétien ou Sparnacien), Transylvanie, Roumanie: les plus anciens mammifères cénozoiques d'Europe Orientale. Eclogae geologie Helvetiae, 92 (1999): 517-535, Basel.

HOFMANN, K., 1879, Bericht über die im östlichen Theile des Szylágyer Comitates während der Sommer-campagne 1878 vollführten geologischen Specialaufnahmen. Földtani Közloni, IX, 5-6 : 231-283, Budapest.

KOCH, A., 1894, Die Tertiärbildungen des Beckens der Siebenbürgischen Landestheile. I. Paläogene Abtheilung. Mitteilungen aus den Jahrbuch der Kön. Ungarische Geologischen Anstalt, X, 6: 177-399, Budapest. of the

MÉSZÀROS, N., 1995, Marine deposits in the continental deposits Jibou Formation. Studii și cercetă ri, 1: 59-61, Bistriț a.

MÉSZÀROS, N., MOISESCU, V., 1991, Bref aperçu des unités lithostratigraphiques du Paléogène dans le Nord-Ouest de la Transylvanie (région de Cluj-Huedin), Roumanie. Bulletin informatif des géologues du Bassin de Paris (1991), 28, 2: 31-39, Paris.

NOPCSA, F., Baron von, 1905, A Gyulafehérvár, Déva, Ruszkabánya és a Romániai határ közé eső vidék geológiája. A magyar Királyi földtáni Intézet Évkonyve., XIV: 82+254, 82 abr., 1 pl. Budapest.

POPESCU, B., 1976, Sedimentology of Priabonian carbonate rocks. Jibou area, N.W. Transilvanian Basin. Anuarul Institutului de Geologie și Geofizică , XLVIII: 117-140, București.

POPESCU, B., 1978, On the lithostratigraphic nomenclature of the NW Transilvania Eocene. Revue Roumaine de Géologie, Géophysique et Géographie, Géologie, 22: 99-107, Bucuresti.

RĂ ILEANU, GR., SAULEA, E., 1956, Paleogenul din regiunea Cluj-Jibou. Anuarul Comitetului Geologic, XXIX: 271-308, București.

RUSU, A., 1995, Eocene formations in the Că lata region (NW Transylvania): a critical review. Romanian Journal of Tectonic \& regional Geology, 76: 59-72, București.

SĂ NDULESCU, M., 1984, Geotectonica României. Editura tehnică , 336 p., București. 